Erratum

\title{
Erratum to "Preconditioning of Rat Bone Marrow-Derived Mesenchymal Stromal Cells with Toll-Like Receptor Agonists"
}

\author{
Fabiana Evaristo-Mendonça, ${ }^{1}$ Gabriela Sardella-Silva, ${ }^{1}$ Tais Hanae Kasai-Brunswick, ${ }^{2}$ \\ Raquel Maria Pereira Campos, ${ }^{1}$ Pablo Domizi, ${ }^{1}$ Marcelo Felippe Santiago, \\ Ricardo Augusto de Melo Reis, ${ }^{1}$ Rosalia Mendez-Otero ${ }^{(D)},{ }^{1,3}$ \\ Victor Túlio Ribeiro-Resende $\mathbb{D}^{1,4}$ and Pedro Moreno Pimentel-Coelho $\mathbb{i D}^{1,3}$ \\ ${ }^{1}$ Instituto de Biofísica Carlos Chagas Filho, Universidade Federal do Rio de Janeiro, Rio de Janeiro, RJ 21941-902, Brazil \\ ${ }^{2}$ Centro Nacional de Biologia Estrutural e Bioimagem (CENABIO), Universidade Federal do Rio de Janeiro, Rio de Janeiro, \\ RJ 21941-902, Brazil \\ ${ }^{3}$ Instituto Nacional de Ciência e Tecnologia em Medicina Regenerativa, Rio de Janeiro, RJ 21941-902, Brazil \\ ${ }^{4}$ Núcleo Multidisciplinar de Pesquisa em Biologia (Numpex-Bio), Campus de Duque de Caxias Geraldo Guerra Cidade, \\ Universidade Federal do Rio de Janeiro, Duque de Caxias, RJ 25255-030, Brazil
}

Correspondence should be addressed to Pedro Moreno Pimentel-Coelho; pedrompc@biof.ufrj.br

Received 22 July 2020; Accepted 22 July 2020; Published 21 August 2020

Copyright (c) 2020 Fabiana Evaristo-Mendonça et al. This is an open access article distributed under the Creative Commons Attribution License, which permits unrestricted use, distribution, and reproduction in any medium, provided the original work is properly cited.

In the article titled "Preconditioning of Rat Bone MarrowDerived Mesenchymal Stromal Cells with Toll-Like Receptor Agonists" [1], there was an error in the production of Figure 2(b) which resulted in some colouration being lost. The publisher apologises for introducing this error, and the corrected figure is shown below and is listed as Figure 1: 

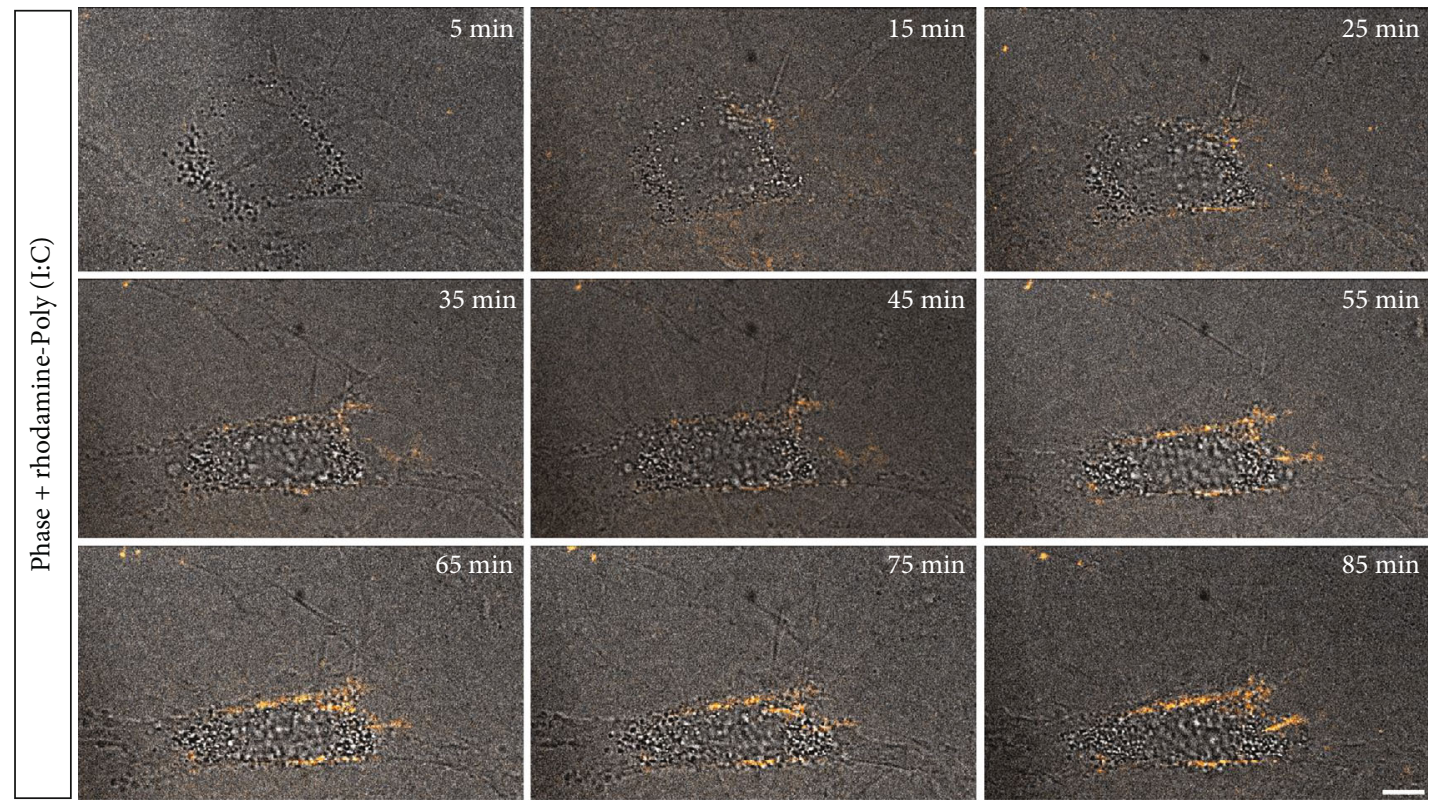

(a)

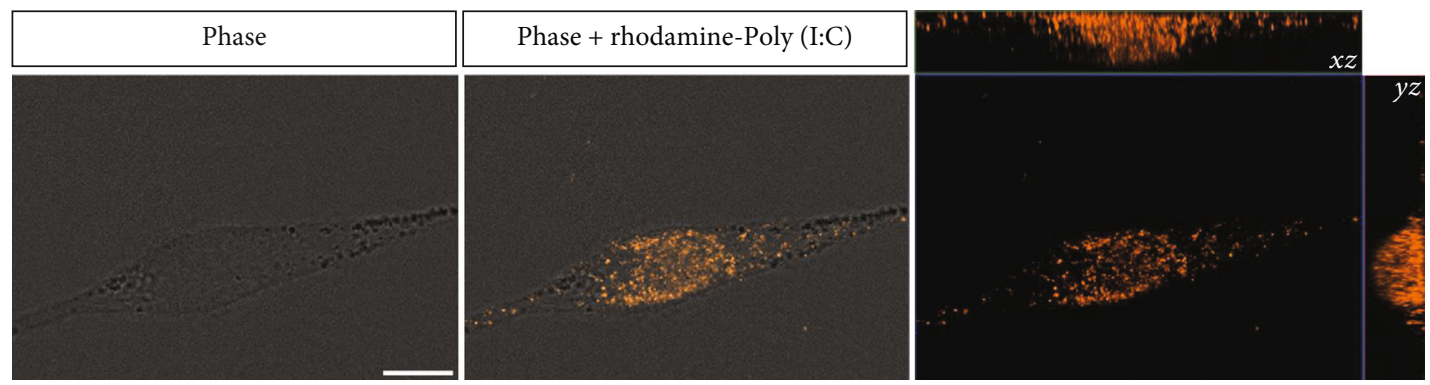

(b)

FIGURE 1: Internalization of rhodamine-conjugated polyinosinic-polycytidylic acid (Poly(I:C)) by rBM-MSCs. (a) Representative photomicrographs from time-lapse video microscopy, each corresponding to the indicated time points following the addition of rhodamine-conjugated Poly(I:C) to the culture medium, showing the overlay of phase contrast and spinning disk confocal fluorescence images of one cell (rhodamine-conjugated Poly(I:C) is shown in red). Scale bar: $10 \mu \mathrm{m}$. (b) On the left, phase contrast image of a cell at $1 \mathrm{~h}$ after incubation with rhodamine-conjugated Poly(I:C). On the center, overlay of the phase contrast image and the maximum intensity projection of a $\mathrm{z}$ stack showing rhodamine-conjugated Poly(I:C) in red. On the right, orthogonal projections (XZ, YZ) of the $\mathrm{z}$ stack showing the internalization of rhodamine-conjugated Poly(I:C) (in red) by this cell. Scale bar: $10 \mu \mathrm{m}$.

\section{References}

[1] F. Evaristo-Mendonça, G. Sardella-Silva, T. H. Kasai-Brunswick et al., "Preconditioning of Rat Bone Marrow-Derived Mesenchymal Stromal Cells with Toll-Like Receptor Agonists," Stem Cells International, vol. 2019, Article ID 7692973, 18 pages, 2019. 